\title{
Loss of laten-support in Embedded Infinitivals in 15th century Low Saxon
}

\author{
Gertjan Postma \\ Meertens Institute Amsterdam
}

\subsection{Introduction}

The rise of $d o$-support in the history of English has a prominent place in diachronic studies, (Ellegård 1953, Visser 1963, Denison 1985, Kroch 1989). In Kroch's study, do-support is one of the four diachronic changes that illustrate his Constant Rate Hypothesis (CRH). The CRH allows us to identify two diachronic processes with distinct actuation times but equal rates, as being realizations of one underlying parametric change. Only if two changes display equal process rates in the E-language, they can be related to one process in the I-language. In the case of $d o$-support, the $\mathrm{CRH}$ allows Kroch to assume that $d o$-support in questions (V-to-C) and in negative declaratives (V-to- $\mathrm{T}$ ), as one and the same grammatical process, despite the fact that the change occurs later in negative declaratives. Kroch links both changes to a shared change in the properties of VP, which has become opaque for verbal extraction (Roberts 1985, Pollock 1989). In a phase-type analysis, we can tie the two processes to properties of the $v \mathrm{P}$-edge. It crucially depends on the status of $v \mathrm{P}$ as a phase. If, on the other hand, the two processes can be shown to be distinct, the two types of do-support are probably tied to changes in some intermediate projection or to the landing site, CP or TP, respectively.

In this paper we study a periphrastic construction ("do-support") in a 15th century Low Saxon dialect in the Netherlands. The periphrasis shows up quite differently because of the basic OV nature and the strict V2 character of the dialect. It enables us to view the locus of verb movement from a different perspective. This 15th century Low Saxon variant exhibits a change in the verbal system that is similar to what happens in the history of English but its direction is reverse: Low Saxon dialects in the Netherlands lost auxiliary support and lost a separate auxiliary class. It turns out that not so much changes in $\mathrm{VP} / v \mathrm{P}$ but changes in the properties of TP and CP are at the basis of changes in laten-support.

\subsection{Infinitival verb fronting}

Coastal continental Germanic has a scarcely documented and poorly understood construction where an embedded clause-final infinitival verb undergoes fronting (henceforth: "Infinitival V2 or IV2") to a clause initial position. ${ }^{1}$ It is a subordinate construction where the subordinate clause is introduced by a coordinator rather than a subordinator, of the type try-and-do in

\footnotetext{
${ }^{1}$ Our IV2-terminology is theoretically driven and presumes that the moved infinitival occupies a headposition. It shows up as a V1-effect observationally, just as we see in imperatives, yes/no questions, conditionals, etc., but we assume that the target is the structural second position in the clause (C).
} 
modern English, illustrated in (1a). In Continental Germanic, the coordinative construction shows the second conjunct in VO order whereas the first conjunct shows the standard OV order, as represented in (1b).

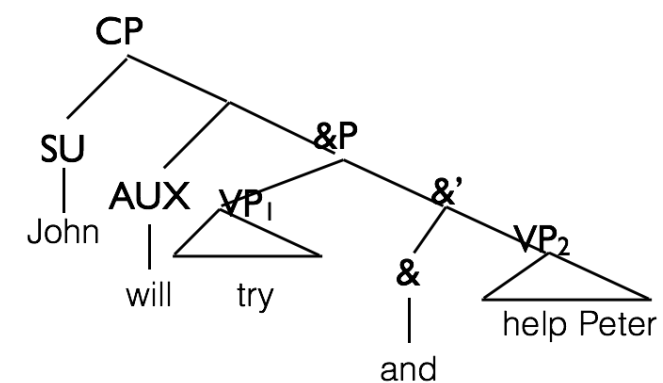

a. and

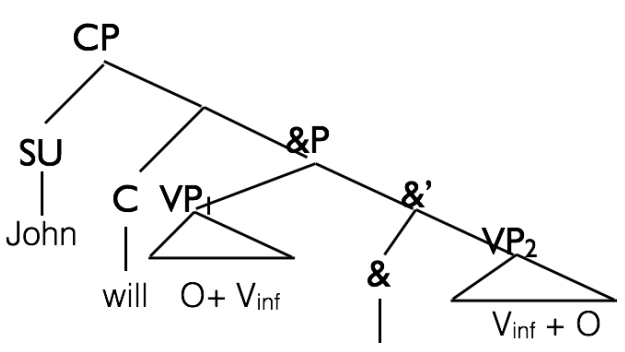

b.

and

This curious construction can be found in Old-Frisian (2), Middle-Dutch (3), and some modern coastal Dutch dialects still had it in the 19th century (4). It is not found in Standard modern Dutch. In the next examples, we listed the main verb in bold and its complement in italics. Conjuncts after ende 'and' systematically show VO order.

(2) Soe scellet hya dae nesta riocht dei deer ney weer [toe riocht gaen] ende [nyment als nw scold wessen habba] (Old Frisian, Sneker Recesboek) so shall they the next law day there after again to court go.inf and take.inf-it as now should be have

'Hence they shall go to court the next law day after it and (they shall) take it as if it now had taken place'

(3) Ende men sal [al die vorseide dingen pulveren] ende [mingen metten zape van ruten] ende [maken pillen] (Middle Dutch, Cyrurgie, Jan Yperman) and one shall all those before-mentioned things grind.inf and mix.inf with soap from rue (a plant: ruta graveolens) and make.inf pills

'and one shall grind all the above ingredients and mix them with ruta soap and make pills'

(4) We zelle [te waa gaen] en make de vleet op order we shall to net go.inf and make.inf the drift-net in order 'we shall go to the nets and make the drift nets in order'

(Dutch dialect of Katwijk, apud Overdiep 1937)

Notice that the clitic object ' $t$ 'it' appears to the right of the infinitive nymen 'take' in the Frisian construction in (2), despite the fact that standard embedded clauses realize OV order. In these dialects, clitic objects scramble beyond the position of the full NP subject. In (2), the infinitival (!) verb nymen 'take' appears even to the left of this scrambled position. The infinitive, therefore, must move quite high up in the syntactic tree. Similar considerations hold for Middle Dutch and dialectal Dutch. ${ }^{2}$

\footnotetext{
${ }^{2}$ De Haan (2010:132 [1990]) mentions the construction in passing in his study of the imperativus pro infinitivo (IpI) construction in Modern Frisian.
} 


\subsection{Infinitival fronting in 15 th century Low Saxon}

Recently, a corpus has been made available of North-Eastern Dutch 15 th century verdicts. ${ }^{3}$ Interestingly, the IV2 construction occurs abundantly, probably because of the modal nature of most verdicts. In (5-6) two typical instances are listed.

(5) Item tusschen den Konen ende den smyt to Legele, wyl de Kone erffnysse hebn, so moet hy en rechte ansetten ende laten hem vertugen.

item between the Krones and the smith in Legele: will the Krone heritage have, then must he a lawsuit start and let.inf him defend-through-witnesses

'Similarly between the Krone-family and the smith in Legele: if Krone wants to inherit, he must start a lawsuit and defend himself through witnesses'

(6) Mach Claes 12 van synen magen, (...), an syn hant nemen ende maken hem der saeke onsculdich, dair hy voir angesproken was, so ....

may Claes 12 of his family (...) in his had take and make him in-the case unguilty, which he for called was, then ......

'if Claes can take in his hand 12 of his family members and (if he can) prove himself not-guilty in the case that he was called for, then ....'

Semantically, the modal verb, moet 'must' in (5) and mach 'may' in (6), has scope over both conjuncts. The coordinative structure of these verdicts can be analyzed as VP coordinations in the scope of this auxiliary (7a) or, alternatively, as CP-coordinations (7b).

$$
\begin{array}{lll}
\text { a. } & \mathrm{XP} \text { AUX SU }\left[\mathrm{VP}_{1} \text { and } \mathrm{VP}_{2}\right] & \mathrm{VP}_{1}=\mathrm{OV}, \mathrm{VP}_{2}=\mathrm{VO} \\
\text { b. } & \mathrm{XP}\left[\left[\mathrm{CP} 1 \text { AUX SU VP } \mathrm{VP}_{1}\right] \text { and }\left[\mathrm{CP} 2 \mathrm{AUX} \text { pro } \mathrm{VP}_{2}\right]\right] & \mathrm{VP}_{1}=\mathrm{OV}, \mathrm{VP}_{2}=\mathrm{VO}
\end{array}
$$

If we analyze them as VP coordinations, the scope issue is straightforward, but we must assume two different base-generated VPs or we must assume verb fronting to the edge of the second VP. Both assumptions would be ad hoc. If we analyze them as CP-coordinations in (7b), we must assume an empty modal in the second conjunct. The fronting can be identified as V-to-C. Both assumption are not ad hoc. The first ingredient is assumed in Kayne (1992) for imperative constructions, which share the MUST modality of these verdicts. Secondly, such embedded AUX to COMP constructions has been reported independently in Romance (Rizzi 1982) and Germanic (Hoeksema 2003). We only have to assume a fronted empty AUX, the empty modal, that carries the main verb with it, i.e. the lexical verb must have incorporated into the empty AUX. For a full justification of the V-to-C analysis of these verdicts, I refer to Postma (2006ab). In this context I would like to add an extra empirical argument, drawn from the infinitive-clitic order, as observed in (8). In (8b) we see that the scrambled object clitic $t$ is higher than the lexical subject oir oem. If we assume a low position of this subject, say in specVP, the object clitic must be above VP. This implies that the second conjunct is certainly larger than VP.

(8) a. dye sal en recht ansetten ende wynnen-t myt enen buyrtuge ende overluden he-TOP shall a lawsuit start and win.inf-it with neighbour-witness and authorities

'he shall start a court and gain it with witnesses and authorities'

\footnotetext{
${ }^{3}$ First published in Keverling Buysman (1987). For a more detailed description, cf. Postma (2006).
} 
b. So mach-t oir oem nyet wedder sprecken so may-it her uncle not against speak 'therefore, her uncle may nor deny it'

We will not make a decision whether the embedded constituent is a projection of $\mathrm{T}$ or $\mathrm{C}$. We will simply opt for the CP implementation.

We found more than 231 instances of this otherwise rare construction. Because of its frequency in this juridical corpus $(>200,000$ words), the construction can be studied diachronically with quantitative means. In Table 1.1 we give the breakdown over the 15 th century.

\section{TABLE 8.1 Breakdown of occurrence of IV2 in 15th century Drenthe}

\begin{tabular}{llll}
\hline year & IV2 & \#words & $\begin{array}{l}\text { IV2 per } \\
1000 \mathrm{w}\end{array}$ \\
\hline 1400 & 6 & 10059 & 0.59648 \\
1402 & 8 & 9438 & 0.84764 \\
1406 & 9 & 10000 & 0.90000 \\
1412 & 7 & 10097 & 0.69328 \\
1418 & 11 & 10739 & 1.02430 \\
1423 & 18 & 12712 & 1.41598 \\
1428 & 26 & 13851 & 1.87712 \\
1432 & 17 & 13096 & 1.29811 \\
1437 & 6 & 13594 & 0.44137 \\
1441 & 7 & 13309 & 0.52596 \\
1448 & 6 & 9521 & 0.63019 \\
1452 & 8 & 11600 & 0.68966 \\
1455 & 9 & 11100 & 0.81081 \\
1461 & 6 & 9900 & 0.60606 \\
1466 & 9 & 10500 & 0.85714 \\
1461 & 8 & 9600 & 0.83333 \\
1475 & 7 & 8900 & 0.78652 \\
1480 & 10 & 9100 & 1.09890 \\
1485 & 12 & 11000 & 1.09091 \\
1490 & 6 & 11600 & 0.51724 \\
1495 & 24 & 10000 & 2.40000 \\
1500 & 11 & 10100 & 1.08911 \\
\hline & & & \\
\hline
\end{tabular}

In Figure 8.1 we have plotted the global values in a graphic and fitted it with a straight line. The incidence remains relatively constant over this century. 


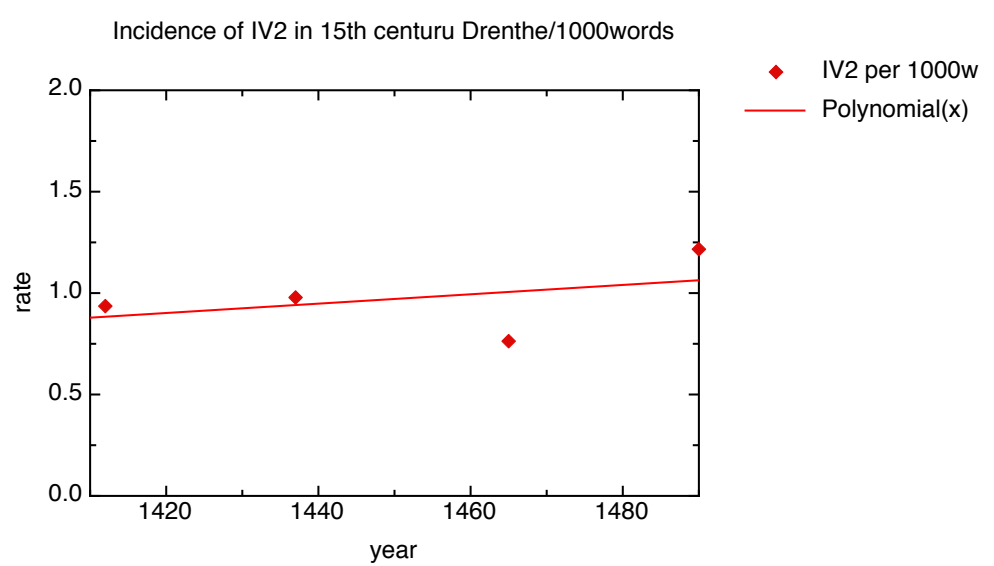

FIGURE 8.1 Occurrence of IV2 in 15th century Drenthe per 1000 words.

If anything changes here at all, there is a slight increase (slope $=2.3062 \mathrm{e}-3 \pm 3.5469 \mathrm{e}-$ $3 / 1000$ words.year). For our purposes, we may consider the incidence of IV2 constant over this century.

\section{Laten-support}

In the previous section, we saw a movement of the infinitive to a clause-initial position (past the clitic position) after the coordinator ende 'and'. It can be observed over a period of 100 years. This movement was not without cost. There is evidence that already during this century, there are style variants in which the infinitival verb could not move. Instead, a dummy verb laten is inserted and undergoes the fronting. An example is given in (9a).

(It is sentenced by the judges ...)

a. ..., dat Herman een rochte ansetten sal (...) ende laten die overlude laeden ende wes hem die overluede myt den bueren toe tugen, dair sall mede hene gaen (Etstoel, verdict 924) ...that Herman a lawsuit start shall (...) and let.inf the authorities invite, and whatever to-him the authorities with the neighbours PRT sentence.inf, there shall (it) with PRT go

'...that Herman must start a court amd must invite the authorities, and what the authorities with the neighbours sentence, that way it will proceed'.

b. ..., dat Johan Staels een rochte ansetten sall ende laden de bruytluden ende wes hem die bruytlude toe tugen, dair salt mede henne gaen. (verdict 1039) ..., that Johan Staels a lawsuit start.inf shall and invite the bride-people and what to-him the bride-people PRT witness.pl, there shall

...that Johan Staals must start a court and must invite the bride's family and what the bride's family decide for him, that way it will proceed'.

The causative/permissive verb laten 'let/make' does not contribute a lexical meaning in this construction with main verb laeden 'invite'. In (11b) we give a parallel verdict without auxiliary: the lexical verb laeden fronts itself. The two verdicts are unfortunately not two versions of the same verdict but they are clearly parallel.

A first piece of evidence that laten is not an ordinary lexical verb in the IV2 construction is the fact that the incidence of laten in this construction is significantly higher $(11 \%)$ than the overall incidence of laten in all contexts $(2 \%)$ justifies. The cross table is given in Table 8.2. 


\section{TABLE 8.2 Correlation table of IV2 and laten}

\begin{tabular}{lll}
\hline cross-table & all verbs & laten \\
\hline in text as a whole & 4102 & $95(2 \%)$ \\
in IV2 contexts & 234 & $26(11 \%)$ \\
\hline
\end{tabular}

The deviance from the expectation value is highly significant $(\mathrm{p}<0.001)$.

The second piece of evidence is the fact that the frequency of laten in this construction disappears in the course of the second half of the 15th century. Later on, it suddenly shows up again when another scribe takes duty in the last decade of the 15 th century. It would be difficult to explain if laten had a lexical causative or permissive meaning in this construction. So while the total occurrence of laten has virtually a relatively constant incidence during this century, indicated in Figure 8.2, the incidence in IV2 has a lot more dynamics, as visualized in Figure 8.3.

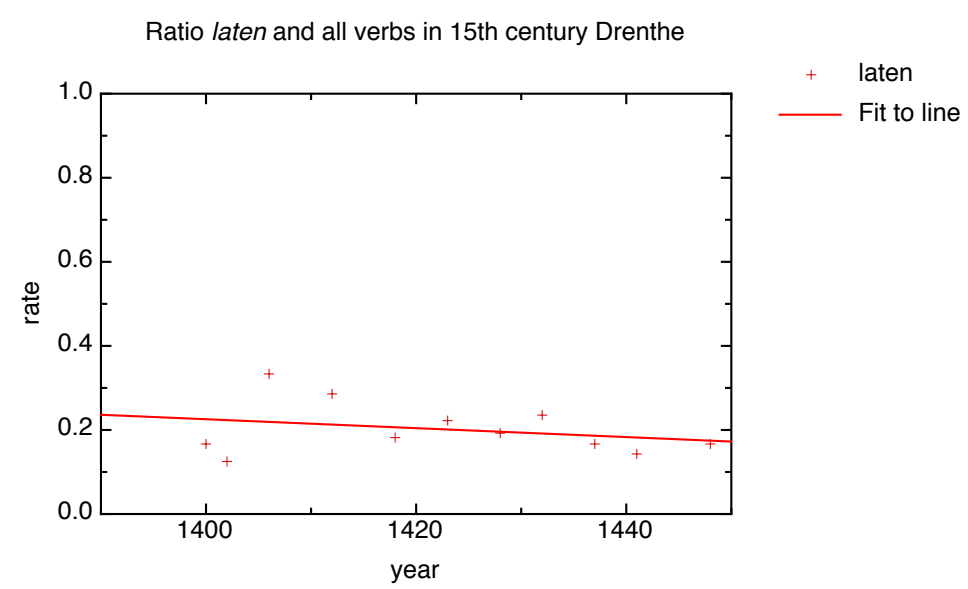

FIGURE 8.2 Ratio of laten/all verbs in 15th century Drenthe

In the table in (15) we give the values of incidence of the periphrastic construction. It may be clear that the laten in the construction in cases behave substantially different and shows extreme behaviour.

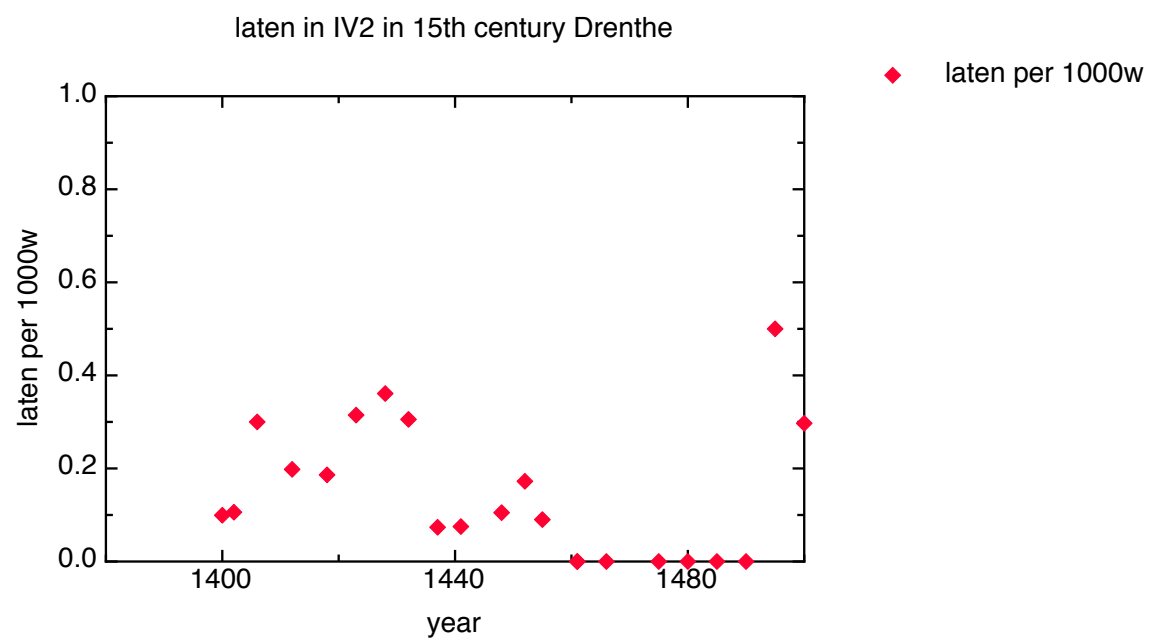

FigURE 8.3 Relative frequency of laten in 15th century Drenthe in tokens/1000 words 
In the first half on the century, the incidence is substantial but rather jumpy, but disappears in the second part. At the end of the century, laten shows up suddenly again. It is probable that this is due to inhomogeneity in the verdicts, for instance, change of a scribe with a different taste or dialect. Nevertheless it is possible to draw conclusions if we average over these extremes and consider it an exponent of an underlying gradual change. Below, we have tabulated the laten incidence with respect to the total occurrence of IV2.

TABLE 8.3 Absolute and relative use of laten as periphrastic auxiliary

\begin{tabular}{llll}
\hline year & $\begin{array}{l}\text { Laten in } \\
\text { IV2 }\end{array}$ & \#words & $\begin{array}{l}\text { laten in IV2 } \\
\text { total IV2 }\end{array}$ \\
\hline 1400 & 1 & 10059 & 0.16667 \\
1402 & 1 & 9438 & 0.12500 \\
1406 & 3 & 10000 & 0.33333 \\
1412 & 2 & 10097 & 0.28571 \\
1418 & 2 & 10739 & 0.18182 \\
1423 & 4 & 12712 & 0.22222 \\
1428 & 5 & 13851 & 0.19231 \\
1432 & 4 & 13096 & 0.23529 \\
1437 & 1 & 13594 & 0.16667 \\
1441 & 1 & 13309 & 0.14286 \\
1448 & 1 & 9521 & 0.16667 \\
1452 & 2 & 11600 & 0.25000 \\
1455 & 1 & 11100 & 0.11111 \\
1461 & 0 & 9900 & 0 \\
1466 & 0 & 10500 & 0 \\
1461 & 0 & 9600 & 0 \\
1475 & 0 & 8900 & 0 \\
1480 & 0 & 9100 & 0 \\
1485 & 0 & 11000 & 0 \\
1490 & 0 & 11600 & 0 \\
1495 & 5 & 10000 & 0.20883 \\
1500 & 3 & 10100 & 0.27270 \\
\hline
\end{tabular}

The question is, therefore, what this underlying development consists of, and what it looks like diachronically. If laten is inserted in the IV2-construction for some morphosyntactic reason, its highest possible incidence is $100 \%$. This means that the low values that we encounter in (15), i.e. around $20 \%$, is either the final tail of a disappearing laten-support or a beginning of a newly created laten-support. In the diagram, we have fitted these two possibilities to the data. Third, there is possibility that laten-support is a transitory effect (failed change in the sense of Postma 2010) that marks the transition period of some deeper change, which can be fitted by a logistic peak. ${ }^{4}$ We have fitted these three scenarios to the data. The three fits are given in (16) and are of quite different accuracy: 1. the rising logistic gives a bad fit: the error in the value $\left(4.7 \times 10^{19}\right)$ is various orders of magnitude higher that the fitted value $\left(6.2 \times 10^{12}\right)$, which is itself a meaningless huge number. This model can be ruled out on the basis of this fit.

\footnotetext{
${ }^{4}$ A failed change is a product of two logistic functions with equal but opposite slopes. The formula used in the three-parameter fitting process is: $\mathrm{f}(\mathrm{x})=\mathrm{a}[3] *(1 /(1+\exp ((\mathrm{x}-\mathrm{a}[1]) / \mathrm{a}[2]))) *(1 /(1+\exp$ $((\mathrm{a}[1]-\mathrm{x}) / \mathrm{a}[2])))$, with $\mathrm{a}[3]$ the saturation value, $\mathrm{a}[1]$ the actuation time, and $\mathrm{a}[2]$ the slope.
} 


\section{GERTJAN POSTMA}

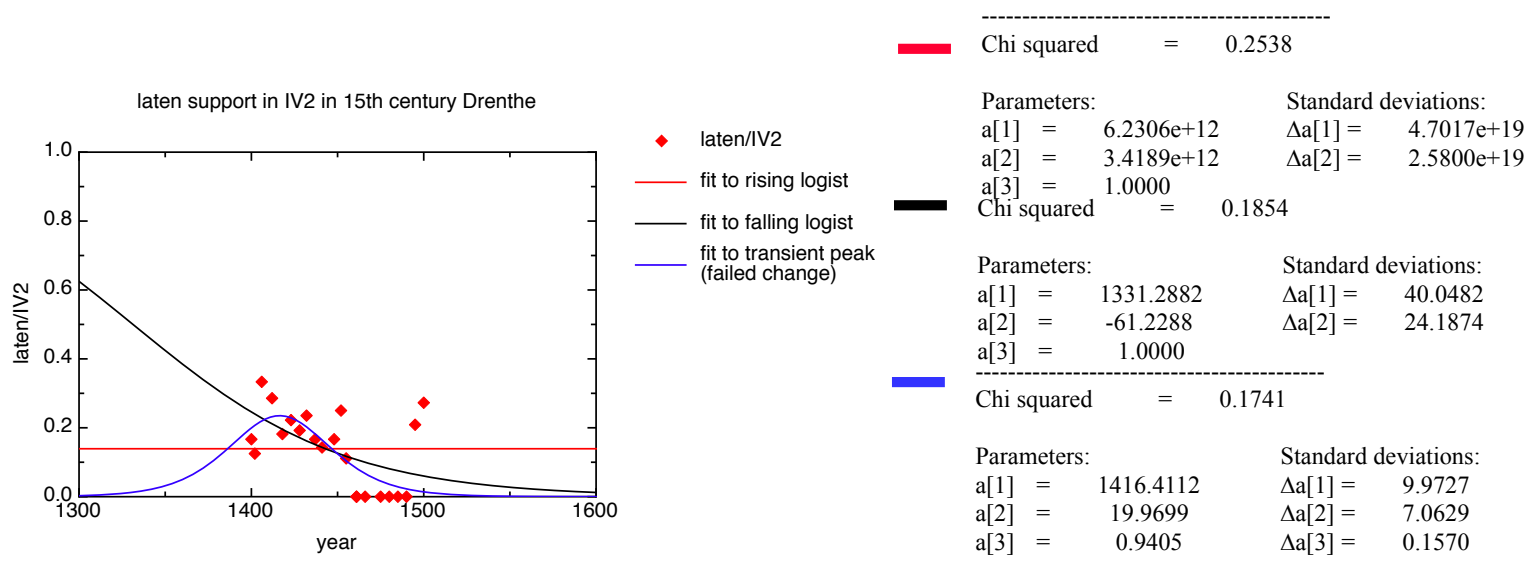

FIGURE 8.4 Three fits to observed data on laten-support in 15th century Drenthe

The other two fits, the falling S-curve and a bell-shaped curve are reasonable, of which the transient peak is the better one. The values and the errors are in (17).

$$
\begin{array}{lll}
\text { a. } & \text { falling logistic } & \\
\text { actuation time: } & 1331 \pm 40 \\
\text { slope parameter: } & -61 \pm 24
\end{array}
$$

b. logistic peak

$$
\begin{array}{ll}
\text { actuation time: } & 1416 \pm 10 \\
\text { slope parameter: } & 19 \pm 7
\end{array}
$$

In the falling logistic model, the interpretation is that the loss of laten-support started far before the documentation in this corpus. If this is the case, then what we see are the last remnants of a previously more general laten-support stage. If the transient peak with a maximum around 1416 is the correct interpretation, we are dealing with an ephemeral change that occurs during this century and might correlate with another, more successful change in the corpus. This will be studied in the next section.

\section{IV2 as a subjunctive construction}

The IV2-construction only occurs under modal verbs, not for instance in AcI or ECM constructions. ${ }^{5}$ More specifically, it is only realized under MUST modality, not under CAN modality. One might think that this is due to the character of these juridical verdicts which might favour MUST. Other modalities, however, do occur though, and never license IV2. In (11) we give some frequencies, taken from Postma (2006).

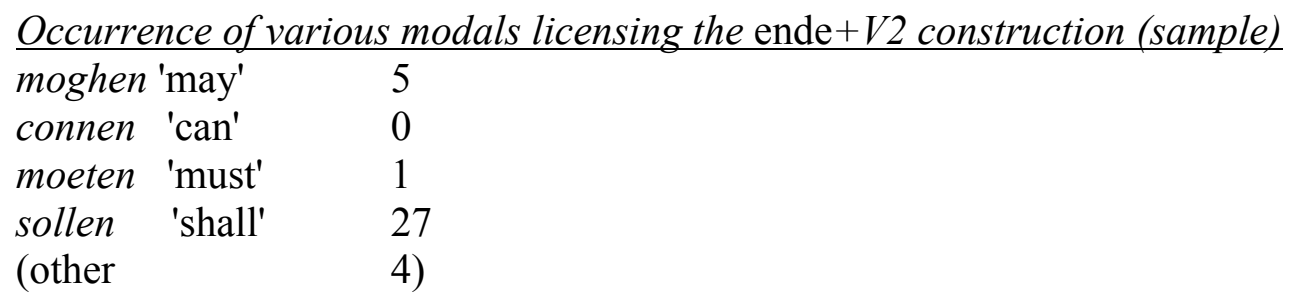

In order to understand the bias to MUST modality, it is instructive to look at the construction that developed from this IV2-construction: the modern Frisian Imperativus-pro-Infinitivo construction (IpI), as studied in De Haan (2002). In modern Frisian, this IpI-construction

\footnotetext{
${ }^{5}$ Accusativus cum infinitivo (AcI) and Exceptional case marking (ECM).
} 
occurs in two contexts: 1. polarity contexts and 2. intentional contexts, exemplified in (12) and (13) respectively.

Jelle tocht der net oan en knip syn hier ôf

Jelle thought there not at and cut.imp his hair off'

'Jelle did not fancy that he would cut his hair short'

(13) Dan sil de polysje grif komme en helje him op

(polarity subjunctive)

Then shall the police PRT come and take.imp him away

'Then the police wil come for sure to take him away'

As was argued in Postma (2006b), the modern Frisian successor of the IV2 construction covers the entire range of the Romance subjunctive: the polarity subjunctive (12) and the intentional subjunctive (13), studied in Stowell (1993) and Quer (1998). The Middle Low Saxon construction is limited to the intentional subjunctive contexts. We therefore interpret the IV2-construction as an infinitival realization of a subjunctive context (similar to what is observed in the Balkan languages), and we might think its increase and fall, as discussed in section 4, as being related to ongoing changes in the subjunctive verbal inflection in general. In the next section we study such changes in the verbal paradigms using our corpus.

\section{Decline of the finite subjunctive}

In this section, we study the decline of the morphological subjunctive during the 15 th century. The reason is the identification of the IV2-construction as a (intentional) subjunctive construction. Semantically, the well-known finite subjunctive in (14a), with implicit modality, is completely parallel to the IV2 construction of (14b), where the modality is expressed by an overt modal verb and the predicate by an infinitive.

(14) a. ...dat hy en rochte ansette ende winne't als landrecht is binnen 3 wecken that he a lawsuit start.sbj and gain.sgj-it as land.law is within 3 weeks

b. $\quad .$. dat hy sal en rochte ansetten ende winnen't als landrecht is binnen 3 wecken

... that he shall a lwasuit start.inf and win.inf it as land.law is within 3 weeks

'...that he starts a lawsuit and gain it according to country law within 3 weeks'

To study the parallel in the E-language, we searched all unambiguous subjunctive forms in our corpus. ${ }^{6}$ The results are given in Table 8.4. The subjunctive displays a clear decline during this century which might be captured with a falling logistic function.

\section{TABLE 8.4 Occurrence of present subjunctive forms per 10.000 words}

\begin{tabular}{ll}
\hline period & number/10.000 \\
\hline 1405.00000 & 5.30000 \\
1417.00000 & 3.86000 \\
1429.00000 & 2.55000 \\
1440.00000 & 2.47000 \\
1447.00000 & 2.09000 \\
1490.00000 & 1.07000 \\
\hline
\end{tabular}

\footnotetext{
${ }^{6} \mathrm{We}$ used the forms sette 'set', wynne 'win', legge 'lay', late 'let', betale 'pay', kome 'come', ga 'go', brenge 'bring', and neme 'take'.
} 


\begin{tabular}{ll}
\hline 1461.00000 & 0.00000 \\
1470.00000 & 0.00000 \\
1479.00000 & 0.00000 \\
1487.00000 & 0.00000 \\
1496.00000 & 0.00000 \\
\hline
\end{tabular}

Since we do not have an expected value for maximal number of subjunctive forms, we cannot normalize between 0 and 1 . This means we have a three parameter model: not only the actuation and the slope are modified, but also the saturation level. In Figure 8.5 we have rendered these data in a graphic together with the best logistic fit.

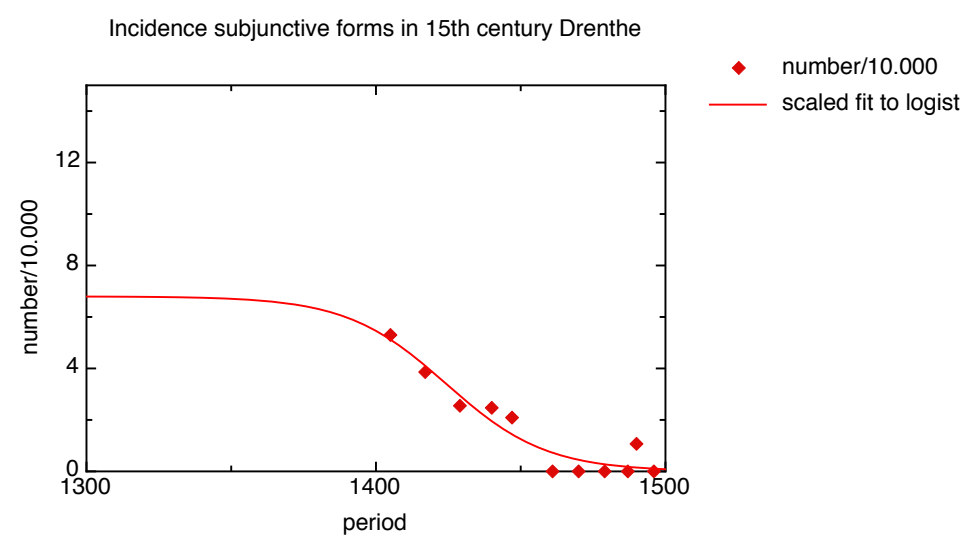

FigURE 8.5 Occurrence rate of present tense subjunctive forms in Low Saxon until 1500.

The fitted parameters are in (15).

$$
\begin{array}{ll}
\text { actuation time: } & 1424 \pm 17 \\
\text { slope parameter } & 17.2 \pm 7
\end{array}
$$

It turns out that this fall in the finite subjunctive can be related to the peak in infinitival subjunctive construction. To see this, it is important to recapture our knowledge of Kroch's Constant Rate Hypothesis.

According to the Constant Rate Hypothesis (Kroch 1989), a parameter change proceeds in different grammatical contexts with equal slope parameters, though their actuation times might be different. Postma (1999) extended the identification of linguistic changes to bell shape curves, changes that emerge and fade out, by tying these to an accompanying successful change, with the same slope parameter, as is illustrated in the exemplar case of the rise of the reflexive in Middle Dutch, as in Figure 8.6. 


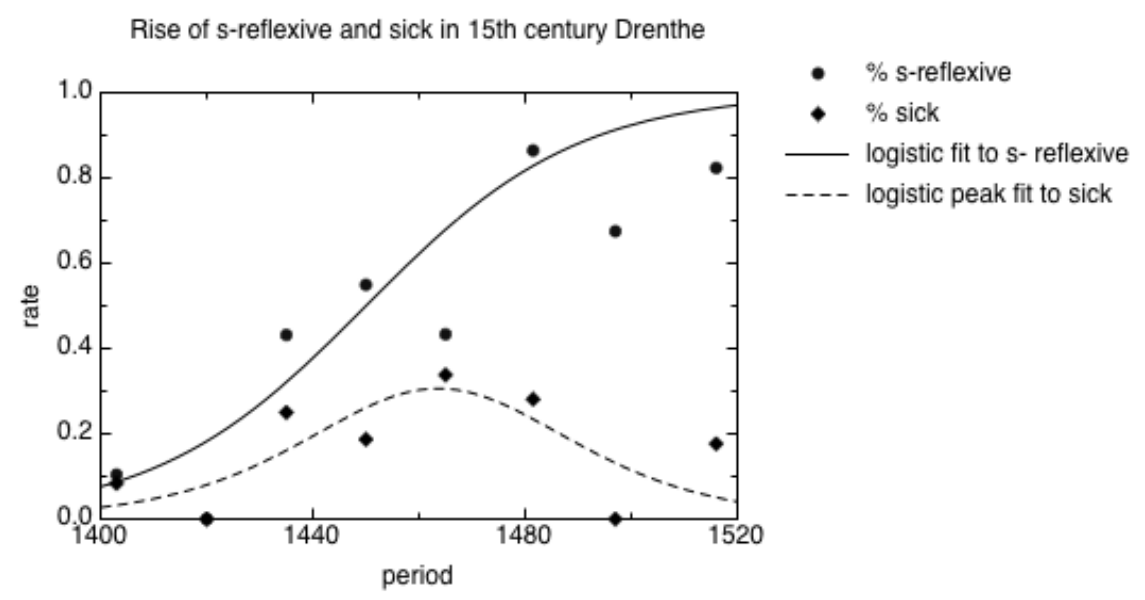

FIGURE 8.6. Rise of sich/sick in reflexive contexts in 15 th century Drenthe

(taken from Postma 2010)

In Figure 8.6, the two changes are related because of one underlying parameter setting: the need of reflexive pronouns. However, they proceed quite differently: the sick form follows a bell-shaped curve, while the overall tendency toward a reflexive form follow an S-shaped curve. Nevertheless, they can be linked by their slope parameters, which turn out to be equal.

We now can apply this methodology to the two changes discussed so far: the rise and fall of the IV2 construction, as visualized in Figure 8.4, with parameters in (10ab) on the one hand, and the disappearance of the subjunctive inflection, as visualized in Figure 8.5, with parameters in (15) on the other hand. Can these changes be related? The Constant Rate Hypothesis implies that if the data on laten-support are to be fitted by a falling logistic, the decline of laten-support and the decline in subjective forms cannot be related, for they have different slope parameters: $-61 \pm 24$ years and $17.2 \pm 7$ years, respectively. These do not overlap within the error. However, we can relate the two changes if we fit the laten-support data to a logistic peak. Just as in Kroch's logistic model, the Constant Rate Hypothesis holds in the failed change model: if the slope parameter of the transient peak and the slope parameter of the logistic are equal, the changes may be related. If we now look at the fitted data, these two changes have - within the error - equal slope parameters: $19 \pm 7$ years for the laten-peak in (10b), and 17.2 \pm 7 years for the subjunctive (15), respectively. This shows that E-language considerations allow us to tie the transient peak of laten-support in the IV2 construction to the decline of the finite subjunctive verbal forms. In the next sections, we provide formal I-language arguments that laten-support and the decline of subjunctives are related to one parameter change in $\mathrm{CP} / \mathrm{TP}$.

\section{The ende+infinitive as T-to-C}

Let us first observe that subjunctive forms have a special relation to $\mathrm{C}$. In earlier stages of English and Dutch, for instance, subjunctives may undergo movement across the subject the king in (16a) and across the subject $I$ in (16b). This is a cross-linguistic pattern. Fronting is complementary to the lexicalization of the complementizer (17). 
(16) a. Long live the king!

b. Were I rich, I would have traveled more

a. That the king live!

b. If I were rich, I would travel more

present subjunctive

past subjunctive

Within a minimalist feature checking system, this can be implemented by assuming that subjunctives are probed by a subjunctive feature above TP. Since subjunctive forms can also remain in situ (17), we assume that the probe is in $\mathrm{C}$ and that checking can induce movement to $\mathrm{C}$ or by AGREE at a distance. The latter is standardly captured by absence or negative value of an EPP feature.

Middle Drentish before 1400

$$
\begin{aligned}
& \mathrm{AGR}_{\text {indicative }} \text { sits in } \mathrm{T} \\
& \mathrm{AGR}_{\text {subjuncvive }} \text { is probed by } \mathrm{C} \text { : }
\end{aligned}
$$

$$
\begin{array}{cl}
\mathrm{C} \text { attracts } \mathrm{AGR}_{\text {subj }} \text { to } \mathrm{C} & (+\mathrm{EPP}) \\
\text { or } \mathrm{C} \text { agrees with } \mathrm{AGR}_{\text {subj }} \text { in situ } & (-\mathrm{EPP})
\end{array}
$$

So, if the ende+infinitive construction is a subjunctive (Postma 2006b), we expect that the landing site is above TP, probably $\mathrm{CP}$ or ModP and the infinitive is attracted by the subjunctive feature in $\mathrm{C}$ or Mod. ${ }^{7}$ The emergence of laten-support in the IV2 construction, therefore, implies that the language imposes restrictions to T-to-C. Before we are looking into the restrictions on T-to-C in more detail in section 9, we first discuss restrictions on V-to-Neg in the next section.

\section{The loss of a separate class of auxiliaries.}

These older North-Eastern texts had a separate class of auxiliaries (Postma \& Bennis 2006). We consider two aspects: the loss of neg-cliticization on verbs (auxiliary versus lexical) and the appearance of infinitival forms 'to $\mathrm{V}$ '. We start with negation. In the first part of the century, the neg-clitic en on $\mathrm{V}$ shows up in $\mathrm{C}$ (together with the verb fronting to C) only if the verb is an auxiliary, cf. mogen 'may' (19a). No instances are found where the fronted verb is a lexical verb (holt 'keeps' in 19b) with a clitic negator. In those cases, the clitic negator is absent, as illustrated in (19b).

(19) a dat en mogen oir oir erffgenamen nyet verbeden that neg may them their heirs not forbid 'Their heirs may not forbid that to them'

b ende (*en) holt hy dair nyet off, machmen om ander werve besaten and keeps he there not off, may-one him other time seize 'and if he does not keep it off, then one may him seize a second time'

So, there is a clear effect of auxiliaries in their interaction with negation. The examples in (19) concern main clauses. In embedded clauses, where no V2 occurs and the verb stays in final position (V-to-T), the effect is reversed: only lexical verbs carry the clitic (significance $\mathrm{p}=0.0002)$.

\footnotetext{
${ }^{7}$ So we interpret the dependend feature of the subjunctive (dependent tense, Progovac 1994, anaphoric tense, Picallo 1985) as an indirect dependency that has $\mathrm{C}$ as an intermediate step. The impoverished nature may be due to this anaphoricity (Motapayane 1995, rather than to incorporation of the subject (Don et al. 2013).
} 
TABLE 8.5 Neg-doubling by a verbal clitic in 15 th century Drenthe in function of the finite verb's position (C/V final) and its auxiliaryhood (Aux/Lex) : 1399-1405 + 1444-1447.

\begin{tabular}{|c|c|c|}
\hline $\begin{array}{l}\text { Negation doubling } \\
\text { in nyet-contexts }\end{array}$ & $\begin{array}{l}\text { main clauses } \\
\text { (V2) }\end{array}$ & $\begin{array}{l}\text { embedded } \\
\text { (Vfinal) }\end{array}$ \\
\hline Aux & $16 / 64 \quad(25 \%)$ & $2 / 86 \quad(2 \%)$ \\
\hline Lexical & $(0 \%)$ & $17 / 40 \quad(42 \%)$ \\
\hline
\end{tabular}

(Data from Postma \& Bennis 2006).

There is no evidence that $\mathrm{V}$ and a clitic negator en form a syntactic complex in embedded clauses. In main clauses, however, we must assume that a fronted verb must have formed a clitic+verb complex, as it has dragged the clitic with it to C. This is apparently only possible with auxiliaries. Hence, incorporation with negation defines a syntactic auxiliary class in the first part of the 15 th century.

In the second part of the century, the auxiliary effect in negation-clitic doubling disappears in both contexts, V-to-C and V-to-T (14), no significant skewing ( $\mathrm{p}=0.8)$.

TABLE 8.6 Neg-doubling by a verbal clitic in 15 th century Drenthe in function of the finite verb's position (C/Vfinal) and its auxiliaryhood (Aux/Lex) : 1488-1492

\begin{tabular}{lllll}
\hline $\begin{array}{l}\text { Negation doubling } \\
\text { in nyet-contexts }\end{array}$ & \multicolumn{2}{l}{$\begin{array}{l}\text { main clauses } \\
\text { (V2) }\end{array}$} & \multicolumn{2}{l}{$\begin{array}{l}\text { embedded } \\
\text { (Vfinal) }\end{array}$} \\
\hline Aux & $2 / 8$ & $(25 \%)$ & $28 / 36$ & $(78 \%)$ \\
Lexical & $2 / 5$ & $(40 \%)$ & $7 / 9$ & $(78 \%)$ \\
\hline
\end{tabular}

(Data from Postma \& Bennis 2006)

This means that the auxiliary class, which can be defined using the clitic negator as a test, disappears around 1450. This development is, therefore, opposite to the development of $d o-$ support and neg-cliticization in English, which increases in time.

The second evidence for a change in the status of auxiliaries is the occurrence of modals after the infinitival marker to/te 'to'. While to/te+modal verb can be observed in the second part, as given in (20), not one case is found in the first half of the 15 th century.

(20) alsdan hebben de gemenen etten angenoemen voir myns heren genaden to reijsen ende tkennen gevende hoer olde rechten toenende ende begeren daer by te moegen blyven, so alse ...

so have.pl the communal judges decided before my Lordship's grace to travel and toknow giving their old rights showing and desire.inf there by to may stay, so

'therefore, the assembled judges have decided to travel to my lord's grace and giving witness to retain their old rights and wish to may stay with these (old rights), hence ...'

We do not have fine grained diachronic data to our disposal. However, in view of the situation in the modern dialects, we may safely assume that the to/te+AUX.inf has increased ever since. Summarizing, there is evidence that, during 15 th century Drenthe, a change was going on in the nature and licensing conditions of T-to-C. 


\section{T-to-C in the history of Dutch}

As subjunctive forms must move to a position above TP (Dobrovie-Sorin 1994), we assume that the verbs we studied in this paper (IV2 and subjunctives) move out of TP to a projection above it, be it C or Mod (as Dobrovie-Sorin assumes). According to Pirvulescu (2006), subjunctives are impoverished forms in the sense of distributed morphology (Halle \& Marantz 1990).

$$
\text { Subjunctive verbal forms have impoverished AGR }
$$

Apparently, only impoverished forms may move out of TP. We, therefore, interpret the developments we discussed above, and which were tied by the Constant Rate Hypothesis (section 6), as both resulting from a language change in TP.

- The loss of subjunctives and the rise of laten support are tied to changes in TP

- Rich verbal forms $\{$ may not/may cross TP

How can we characterize this change, both in observational terms and formally? One way of formulating it, is that the language changed from having an opaque TP to a transparent TP because of deflection (all verbal forms may cross TP). However, this formulation makes reference to structure of the paradigm, i.e. to forms that are potentially present rather than actually present in the construction at hand. Moreover, it is not the case that the indicative inflections becomes deflected, but rather than the (already impoverished) subjunctive forms disappear. Finally, we prefer to have a syntactic cause from which the disappearance of a subjunctive follows and which describes the changes in the paradigms as its consequence. In order to reach that goal we must widen our perspective to the modern situation.

The present-day Dutch dialectal space has a main isogloss that sets Dutch apart form its neighbouring West Germanic variants such as Low German, Frisian and Limburgian. It is given in (23a).

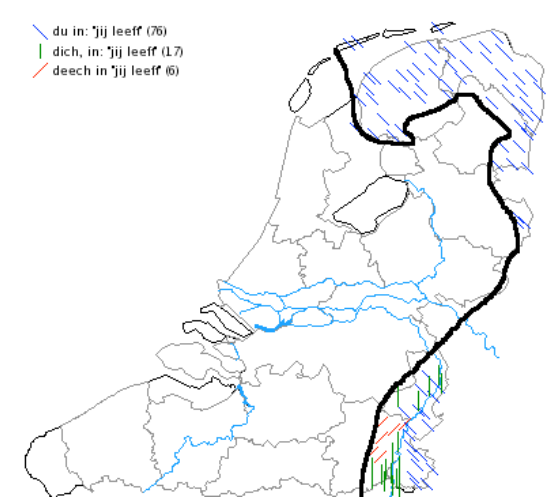

a. Dialects with $d u$ 'thou'

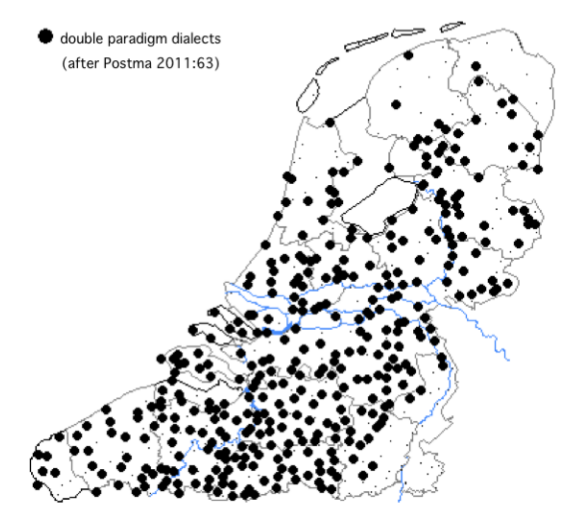

b. Double AGR dialects

The drawn line in (23a) separates the dialects with $d u$ 'thou' (east) from the dialect with $j i j^{8}$ 'you' in the west. Apart form this lexical difference, this line separates dialects that have double inflectional paradigms of verbs, $\mathrm{AGR}_{\mathrm{T}}$ and $\mathrm{AGR}_{\mathrm{C}}$ (west) from dialects with an unitary

\footnotetext{
${ }^{8}$ And its variants, notably Southern gij.
} 
paradigm $A G R_{C}=A G R_{T}$ (east). An $A G R_{T}$ versus $A G R_{C}$ opposition arises in dialects that have blocking of T-to-C in certain contexts (Zwart 1993, Postma 2012).
a. $\quad\left[\mathrm{CP}\right.$ wi $-\quad\left[\mathrm{TP}_{\mathrm{wi}}\right.$ speult op straat $]$
(Modern Low Saxon)
b. [CP dan speul-e [TP wi $t_{V}$ op straat $]$ $\mathbf{A G R}_{\mathbf{C}}$
c. $\quad[\mathrm{CP}$ datt-e $[$ Tе wi speult..............] $]$ (that/then) we play on the street

Den Besten (1987) assumes all V2-sentences to lexicalize C as in (25).
a. [CP wy spylje [TP $t_{\text {wi }} t_{V}$ op 'e strjitte $\left.]\right]$
b. $\quad[$ СP dan spylje [TP wy tV op 'e strjitte] $]$
(Modern Frisian)

So, according to Den Besten, finite $\mathrm{V}$ always ends up in $\mathrm{C}$ in main clauses, both in subjectinitial sentences and in inversion contexts. According to Zwart 1993, the verb sits in $\mathrm{T}$ in subject-initial sentences, but sits in $\mathrm{C}$ in inversion contexts while the subject is always in specTP.

In Postma (2013), a dialect-geographical interpretation of the two theories of V2 is proposed: in the eastern dialects systematically no double paradigms arise (Den Besten's theory). In the western dialects, however, the verb does not always move to $\mathrm{C}$ but stays in $\mathrm{T}$ in subject-initial contexts (Zwart's theory). In the western dialects, there is a block on T-to-C in contexts with a [2p]-feature subject which fronts to the sentence peripheral position. ${ }^{9}$ If a subject without [2] or if any other XP fronts, be it the object or an adjunct, the verb ends up in $\mathrm{C}$, just as in the neighboring West Germanic variants. T-to-C blocking shows up as a special verbal agreement, $\mathrm{AGR}_{\mathrm{T}}$, distinct form the verbal forms that sits in $\mathrm{C}, \mathrm{ARG}_{\mathrm{C}}$ (Zwart 1993). The modern Dutch dialects that have such double $\mathrm{AGR}_{\mathrm{C}}$ and $\mathrm{AGR}_{\mathrm{T}}$ are indicated by the dots in the map in (23b), which is based on the modern MAND database.

Recently, it has been argued that $\mathrm{AGR}_{\mathrm{C}}$ is the impoverished agreement while $\mathrm{AGR}_{\mathrm{T}}$ is the full rich agreement (Ackema \& Neeleman 2003, 2012; Don, Fenger \& Koeneman 2012).

$\mathrm{AGR}_{\mathrm{C}}$ is impoverished $\mathrm{AGR} ; \mathrm{AGR}_{\mathrm{T}}$ is the rich $\mathrm{AGR}$

Comparison with (21) brings us to identify the $\mathrm{AGR}_{\mathrm{C}}$ with the old subjunctive agreement, and $\mathrm{AGR}_{\mathrm{T}}$ with the indicative agreement. As to the shape of the agreement morphemes, this identification is unproblematic (e.g. wi maakt < Old Saxon makoth (indicative, pl) versus make(n) wi < makon (subjunctive, pl)): Modern Low Saxon: wi maakt/dan maken wi). ${ }^{10} \mathrm{We}$, therefore, characterize the change as a change of subjunctive features into positional spellout features. The old subjunctive forms, which were $\mathrm{C}$-directed, are reanalyzed as $\mathrm{C}$-forms, while the old indicative forms are reanalyzed as T-forms.

$$
\begin{array}{lll}
\mathrm{V}_{\text {subj }} & \rightarrow & \mathrm{V}_{\mathrm{C}} \\
\mathrm{V}_{\text {indic }} & \rightarrow & \mathrm{V}_{\mathrm{T}}
\end{array}
$$

In formal terms, this change can be captured as a change in the subjunctive, say, the clause

\footnotetext{
${ }^{9}$ The Postal feature, [2], is present in $2 \mathrm{sg}, 2 \mathrm{pl}$, and $1 \mathrm{pl}$. (inclusive reading).

${ }^{10}$ Similar relations in later Old English: indicative bere gē 'bear you' versus ge berap 'you bear', cf. Brook $(1955, \S 158)$.
} 
typing feature $\mathrm{uX}$. It was the loss of the -EPP feature of $\mathrm{uX}$ and, simultaneously, the extension of $\mathrm{uX}$ into any clause typing feature.

$$
\begin{array}{lll}
\mathrm{uX} & \mathrm{uX} \\
\mathrm{X}=\text { clause typing }\{\operatorname{mood}\} & \mathrm{X}=\text { clause typing }\{\text { Foc } / \text { Top } / \mathrm{WH} / \ldots\} \\
\pm \mathrm{EPP} & +\mathrm{EPP}
\end{array}
$$

If we now go back to our infinitival forms in the IV2 construction, the question arises whether we must characterize the infinitival inflection -en as full or impoverished. Let us start with the situation before the change. Before the 15th century, the "non-positional" period, these infinitives pattern with subjunctives and should therefore also be considered as impoverished, i.e. as $\mathrm{C}$ forms. After the change, i.e. in the second half of the century, the 'positional' period, all infinitives raise to $\mathrm{T}$, both lexical and auxiliary verbs: to maken 'to make', to mogen 'to may', etc. This identifies infinitival -en after the change as a realization of $\mathrm{AGR}_{\mathrm{T}}$. Now during the change, the IV2-construction looks like the structure in (29).

$$
\begin{gathered}
\text { ende }[\text { СP - laten [тр pro .... laden }]]] \\
\text { C }
\end{gathered}
$$

During the change, infinitives are being reanalyzed as sitting in T. However, as we have seen above, the IV2-construction realizes the infinitive in C. This makes it understandable that a separate verbal form is needed as a spellout of $\mathrm{C}$. There are two possibilities: a special inflection exists that sits in $\mathrm{C}$ or, alternatively, $\mathrm{C}$ lexicalizes in a special way. Both strategies are found. In the modern Frisian construction, an existing $\mathrm{C}$-form, the imperative, has extended its domain of usage to subjunctive contexts: the IPI effect. In Low Saxon a specific verbal form was used.

The rise of positional spellout as an abstract change in the I-language is the basis of the observed patterns in the E-language: the decline of the subjunctive and the rise of latensupport. While laten support is a failed change and the loss of the subjunctive a successful change, they are nevertheless tied both formally (positional spellout) and observationally (in the E-language): they have equal process rates.

\section{Conclusions}

In this quantitative corpus study of IV2 in 15th century Low Saxon, we have shown that laten-support in the infinitival V2 construction is tied to the decline of the subjunctive in finite contexts. Both phenomena are quantitatively related in the E-language. Furthermore, we have shown that laten-support, the decline of the subjunctive, and the rise of double paradigms are related in the I-language (positional spellout in $\mathrm{C}$ and $\mathrm{T}$ ). These changes are related to properties of $\mathrm{CP}$ and TP, not of VP. It is unclear yet, why laten-support is a transient phenomenon ("failed change"), but it might have been the trigger of the reshuffle of auxiliaries as ordinary verbs. Laten-support as a specific C-spellout survives in the Frisian imperativus-pro-infinitivo construction (IpI). 


\section{References}

Ackema Peter \& Ad Neeleman (2003). Context-Sensitive Spell-Out. Natural Language \& Linguistic Theory, 21, 681-735.

Besten, Hans den. 1983. On the Interaction of Root Transformations and Lexical Deletive Rules. In: Werner Abraham (ed.). On the Formal Syntax of the Westgermania. Papers from the "3rd Groningen Grammar Talks" Groningen, January 1981. Benjamins: Amsterdam/ Philadelphia. 1983. Linguistik Aktuell 3: 47-131.

Denison, David. (1985). The origins of periphrastic DO: Ellegård and Visser reconsidered. In Papers from the 4th International Conference on English Historical Linguistics, eds. Roger Eaton, Olga Fischer, Willem Koopman and Frederike van der Leek. Amsterdam: Benjamins.

Dobrovie Sorin, Carmen. (1994). The syntax of Romanian. Berlin.

Don, Jan, Paula Fenger \& Olaf Koeneman (2013). Restricting language change through micro-comparative analysis. Talk presented at GLOW, Lund.

Ellegård, Alvar. (1953). The Auxiliary do: The Establishment and Regulation of Its Use in English. In: Frank Behre (ed.). Gothenburg Studies in English. Stockholm: Almqvist and Wiksell.

Haan, G. de (1990). De Friese Imperativus-Pro-Infinitivo. Taal en Tongval 42. Themanummer 3: Dialectsyntaxis (red.: G. de Schutter, M. Gerritsen, C. van Bree), p. 87107.

Haan, Germen J de. (2010). Studies in West Frisian Syntax. Selected papers of. Edited by Jarich Hoekstra, Willem Visser, Goffe Jensma. John Benjamins. Amsterdam.

Haeringen, C.B. van, 1962. Gramarie: keur uit het werk van zijn hoogleraarstijd. Assen, 6874.

Halle, Morris \& Alec Marantz. 1993. 'Distributed Morphology and the Pieces of Inflection.' In: Kenneth Hale and S. Jay Keyser (eds). The View from Building 20, MIT Press, Cambridge, 111-176.

Hoeksema, Jack (2003). Verb Movement In Dutch Present-Participle Clauses. in: Jan Koster en Henk van Riemsdijk (eds), Germania et alia: A Linguistic Webschrift for Hans den Besten: www.let.rug.nl/ koster/DenBesten/Hoeksema.pdf.

Hoekstra, Eric \& Caroline Smits. (1996). Everything you always Wanted to Know about Complementizer Agreement. Proceedings of WECOL. 189-200.

Kayne, R. S. (1992). Italian negative infinitival imperatives and clitic climbing. In: L. Tasmowsky and A. Zribi-Hertz (eds). Hommages à Nicolas Ruwet, 300-312. Communication and Cognition, Ghent.

Keverling Buysman, F. (1987). Ordelen van de Etstoel van Drenthe 1399-1447 and 14501504. Walburgpers, Zutphen.

Kroch, Anthony. 1989. Reflexes of Grammar in Patterns of Language Change. Language Variation and Change 1, 199-244.

Motapayane, V. (1995). Theoretical Implications of Complementation in Romanian. Unipresee, Padova.

Picallo, Carme (1994). Opaque domains. PhD Disssertation, CUNY.

Pirvulescu, Mihaela. (2006). Agreement paradigms across moods and tenses. In: Chiyo Nishida and Jean-Pierre Y. Montreuil (Eds). Morphology, Syntax, Semantics, and Pragmatics New Perspectives on Romance Linguistics. Vol 1. Benjamins. 229-246.

Pollock, Jean-Yves. (1989). Verb Movement, Universal Grammar, and the Structure of IP, Linguistic Inquiry 20, 365-424.

Postma, G.J. (2006a). IV2 in het Middeldrents en de Subjunctief. In: Taal \& Tongval: 57 (1), 126-166. Full text: http://depot.knaw.nl/8932 
Postma, G.J. (2006b). IV2 in het Middelnederlands, IPI in het Fries en de distributie van subjunctieven. In: Taal \& Tongval: 58 (2), 205-224. Full text: http://depot.knaw.nl/8920

Postma, G.J. \& H.J. Bennis. (2006). Variatie in negatie - Het gedrag van het negatieve cliticum in het Middeldrents van rond 1400. In: Taal \& Tongval: 58 (1), 148-166.

Postma, G.J. (2010). The impact of failed changes. In C. Lucas, S. Watts, A. Breitbarth \& D. Willis (Eds.), Continuity and Change in Grammar. Benjamins. 269-302.

Postma, G.J. (2011). Language Contact and Linguistic Complexity - The Rise of the Reflexive Pronoun zich in a 15 th Century Netherlands' Border Dialect. In: Dianne Jonas \& John Whitman (eds.), Grammatical Change - Origins, Nature, Outcomes. Oxford: Oxford University Press. 139-159.

Postma, G. J. (2013). Clause-typing by [2] - The loss of the 2 nd person pronoun $d u$ 'you' in Dutch, Frisian and Limburgian dialects. In: V. Camacho-Taboada, et.al (Eds.), Information Structure and Agreement. (Vol. 197, pp. 217-254). (Linguistik Aktuell/Linguistics Today). Amsterdam: Benjamins.

Progovac, Liliana. (1994). Negative and positive polarity: a binding approach. Cambridge.

Quer, Josep (1998). Mood at the interface. PhD Dissertation. Utrecht University. LOT.

Reenen, Pieter van en Maaike Mulder (1993). Een gegevensbank van 14de-eeuwse Middelnederlandse dialecten op computer. Lexikos 3. http://lexikos.journals.ac.za/pub/ issue/view/75.

Rizzi, Luigi (1982). Italian Syntax. Dordrecht, Foris.

Roberts, Ian. 1985. Agreement Parameters and the Development of the English Modal Auxiliaries. NLLT 3 (1) : 21-58.

Stowell, Tim 1993, The Syntax of Tense. Ms. UCLA.

Verdenius, A.A. (1924). De ontwikkeling der Hollandse voornaamwoorden je en jij. Tijdschrift voor Nederlandse taal- en letterkunde 43, 81-104.

Verdenius, A. A. (1925). Over de aanspreekvorm ie (i-j ) in onze oostelike provincieën. Tijdschrift voor Nederlandse Taal- en Letterkunde 45, 23-32.

Verdenius, A.A. (1942). De laatste sporen van $d u$ in Noord-Holland, De Nieuwe Taalgids 36, 223-227.

Visser, F.T. (1963). An historical syntax of the English language. Brill. The Hague.

Zwart, Jan-Wouter. (1993). Dutch Syntax: A Minimalist Approach. PhD Dissertation, University of Groningen. 